\title{
HUBUNGAN TINGKAT PENGETAHUAN TERHADAP KEBERHASILAN PENGGUNAAN ALAT KONTRASEPSI PIL KB
}

\author{
Diah A. Retanti. ${ }^{1)}$, Pristia Rakhmawati ${ }^{1}$, Fadzrin H. Ningsih ${ }^{1)}$, Zahratus S. Aliyah ${ }^{1)}$, Rosy D. Nurcholida ${ }^{1)}$, Alfis \\ Z. Khoir ${ }^{1)}$, Diyah Pujiastuti ${ }^{1)}$, Mita A. Ardita ${ }^{1)}$, Sonia K. Nisa ${ }^{1)}$, Lovely Q. Ilmiah ${ }^{1)}$, Gusti N. V.Achmad ${ }^{1)}$ \\ ${ }^{1)}$ Fakultas Farmasi Universitas Airlangga \\ Jl. Dharmawangsa Dalam Surabaya 60286 \\ E-mail: diah.ayu.retanti-2015@ff.unair.ac.id
}

\begin{abstract}
ABSTRAK
Alat kontrasepsi merupakan metode yang digunakan untuk upaya pengaturan kehamilan. Berdasarkan data profil Dinas Kesehatan Kota Surabaya Tahun 2016 akseptor pil KB (Keluarga Berencana) tertinggi terletak di Kecamatan Tambaksari yaitu sebesar 4440 akseptor. Namun berdasarkan data WHO, tingkat kegagalan pil KB mencapai 90 per 1000 orang. Hal ini dapat terjadi karena kurangnya pengetahuan dan informasi terkait hal-hal yang dapat menurunkan efektivitas pil KB. Penelitian ini bertujuan untuk mengetahui hubungan tingkat pengetahuan dengan keberhasilan metode pil KB. Penelitian dilakukan di Kecamatan Tambaksari Kota Surabaya pada 100 subjek wanita yang sedang ataupun pernah menggunakan pil KB sebagai alat kontrasepsi. Penelitian dilakukan dengan metode cross sectional dengan teknik sampling non probability sampling. Dari hasil uji statistik yang dilakukan menunjukkan hasil bahwa tidak ada perbedaan signifikan tingkat pengetahuan masyarakat yang berhasil maupun tidak berhasil dalam penggunaan pil KB.
\end{abstract}

Kata kunci: pil KB, keberhasilan pil KB, pengetahuan.

\begin{abstract}
Contraception is a method used to regulate pregnancy. Based on the Surabaya City Health Profile 2016, the highest oral contraception acceptors in Surabaya was citizen in Tambaksari District which 4440 acceptors. However, based on the World Health Organization (WHO) data, the oral contraception failure rate reached 90 per 1000 people. Lack of knowledge and information related to oral contraception may reduce the effectiveness of the pill. The aim of this study was to determine the relationship between the level of knowledge and the effectiveness of the oral contraception method as a contraceptive method. The research method used was cross sectional with a non probability sampling technique. The result showed that there was no significant difference in the level of knowledge of successful and unsuccessful people in using oral contraception.
\end{abstract}

Keywords: oral contraception, effectiveness of contraception, knowledge. 


\section{PENDAHULUAN}

Indonesia merupakan negara dengan laju pertumbuhan penduduk yang masih relatif tinggi (Badan Pusat Statistik, 2013). Oleh karena itu pemerintah berupaya untuk menekan laju pertumbuhan penduduk dengan mengadakan program Keluarga Berencana (KB). Salah satu upaya program KB yakni menurunkan Total Fertility Rate (TFR) guna mengurangi beban pembangunan dan meningkatkan kualitas hidup keluarga. Hal tersebut dimaksudkan agar setiap keluaraga memiliki anggota keluarga yang tidak begitu banyak sehingga diharapkan dapat meningkatkan kesejahteraan hidup keluarga tersebut. Untuk mencapai program $\mathrm{KB}$, alat kontrasepsi merupakan metode yang digunakan sebagai upaya pengaturan kehamilan (Infodatin, 2014).

Metode kontrasepsi dibagi menjadi dua macam yakni Metode Kontrasepsi Jangka Panjang (MKJP) dan metode kontrasepsi non-MKJP. MKJP merupakan kontrasepsi yang dapat dipakai dalam jangka waktu lama lebih dari 2 tahun, efektif, dan efisien seperti Intra Uterine Device (IUD), implan, kontrasepsi mantap dengan Metode Operasi Pria (MOP) dan Metode Operasi Wanita (MOW). Sedangkan non-MKJP merupakan alat kontrasepsi yang bersifat temporer seperti pil KB, suntik, dan kondom (Handayani, 2010).

Berdasarkan data profil Dinas Kesehatan Kota Surabaya Tahun 2016, peserta KB bagi wanita usia subur terbagi menjadi peserta keluarga berencana aktif dan baru. Jumlah Pasangan Usia Subur (PUS) yang menjadi peserta $\mathrm{KB}$ aktif tercatat sebesar $75,19 \%$ dari 486,609 pasangan usia subur. Sedangkan peserta KB baru yang ada di kota Surabaya pada tahun 2016 sebesar 9,59\%. Jumlah PUS terbanyak di Kecamatan Tambaksari tercatat sejumlah 36,983, dengan rincian sejumlah 11,929 di Kelurahan Rangkah, sejumlah 10,370 di Kelurahan Pacar Keling, dan sejumlah 14,684 di Kelurahan Gading (Dinas Kesehatan Kota Surabaya, 2016).

Peserta keluarga berencana aktif dibagi menjadi peserta KB dengan Metode Kontrasepsi Jangka Panjang (IUD, MOP/MOW, dan implan) serta peserta KB Non-MKJP (suntik, pil, kondom, dan lainnya). Peserta KB aktif di Kota Surabaya pada tahun 2016, paling banyak memilih Metode Kontrasepsi Jangka Panjang jenis IUD dengan rincian, IUD 7,51\%, Medis Operasi Wanita (MOW) $5,10 \%$, Medis Operasi Pria (MOP) 0,22\%, dan implan 3,73\%, sedangkan metode Non-MKJP yang paling banyak dipilih jenis suntik dengan rincian, suntik $64,51 \%$, pil $15,94 \%$, kondom 2,99\% dari 365 peserta KB aktif.
Peserta keluarga berencana baru juga dibedakan menjadi peserta KB dengan MKJP dan Non-MKJP. Rata-rata peserta KB baru di kota Surabaya yang menggunakan Metode Kontrasepsi Jangka Panjang terdiri dari IUD 6,39\%, implant 4,13\%, Medis Operasi Wanita (MOW) 1,86\%, Medis Operasi Pria (MOP) $0,17 \%$, sedangkan yang menggunakan Non MKJP terdiri dari suntik $72,60 \%$, pil $9,50 \%$, kondom $5,34 \%$ dari 46.681 peserta KB baru. Berdasarkan data di atas dapat dilihat bahwa, akseptor KB di Kota Surabaya lebih menyukai pemakaian Non MKJP salah satunya pil KB yang menjadi pilihan alat kontrasepsi selain suntik (Dinas Kesehatan Kota Surabaya, 2016). Padahal Couple Years Protection (CYP) NonMKJP hanya berkisar 1-3 bulan yang artinya memberi peluang cukup besar untuk terputusnya penggunaan kontrasepsi (20\%-40\%). Sedangkan CYP MKJP sendiri berkisar 3-5 tahun memberi peluang kelangsungan yang lebih tinggi (Primadi, 2013 dalam Perwiraningtyas dan Prasetyo, 2016).

Dampak utama dari kegagalan KB adalah terjadinya Kehamilan yang Tidak Diinginkan (KTD) (Winner et al., 2012). Data WHO menunjukkan, tingkat kegagalan pil $\mathrm{KB}$ paling tinggi jika dibandingkan bentuk kontrasepsi yang lain yaitu mencapai 90 per 1000 orang sedangkan kegagalan kontrasepsi suntik berkisar 60 per 1000 orang. Sementara itu, implan memiliki angka kegagalan 0,5 persen atau yang paling kecil, bahkan dibandingkan dengan KB IUD sebanyak 8,5 orang (WHO, 2015).

Tingginya angka kegagalan tersebut dapat terjadi karena berbagai alasan seperti kurangnya pengetahuan akseptor pil KB tentang cara pemakaian pil KB yang benar. Selain itu, akseptor juga tidak mengetahui bahwa obat seperti antibiotik dan obat anti kejang bisa menurunkan bahkan menghilangkan efektivitas pil (Fajrin dan Lilis, 2011). Sebaliknya, oral contraception juga dapat menghambat bahkan menghilangkan efektivitas obat lain seperti, beberapa analgesik (parasetamol dan morfin), antikoagulan (warfarin), antidepresan (ipratropium bromida), antidiabetik (glibenklamid), lamotrigin epilepsi (gabapentin), antihipertensi (kaptopril), benzodiazepin, siklosporin, klofibrat, kortikosteroid, dan levoritoksin (Sweetman, 2009).

Efektivitas penggunaan pil $\mathrm{KB}$ masih cukup rendah jika dilihat dari tingginya akseptor yang mengalami kegagalan (kehamilan tidak diinginkan). Akseptor pil KB mempunyai risiko lebih besar untuk mengalami kegagalan dibandingkan metode $\mathrm{KB}$ hormonal lainnya. Angka kegagalan pil KB secara teoritis $0-2,1 \%$ Per sedangkan tingkat kegagalan di lapangan lebih tinggi bisa yaitu 0,79,6\% (Hartanto, 2010 dalam Ermawati, 2013). 
Keberhasilan Pil KB salah satunya diperlukan suatu kedisiplinan atau kepatuhan yang tinggi untuk selalu minum pil KB sesuai dengan jadwal yang ada. Apabila tidak disiplin dalam menggunakan pil KB dikhawatirkan akan terjadi kehamilan, di mana pil KB harus diminum setiap hari dan jika lupa akan meningkatkan angka kegagalan (Ermawati, 2013). Hal yang dapat mempengaruhi kepatuhan salah satunya tingkat pengetahuan (Ermawati, 2013).

Sehingga tujuan dari penelitian ini adalah untuk mengetahui hubungan antara tingkat pengetahuan dengan keberhasilan metode pil KB pada Pasangan Usia Subur (PUS). Penelitian dilakukan di Kecamatan Tambaksari Kota Surabaya yang memiliki peserta KB aktif paling tinggi yaitu Kecamatan Tambaksari, dimana sebesar 23482 untuk peserta KB aktif Non-MKJP dan 3874 untuk peserta KB aktif MKJP. Selain itu pengguna pil KB terbanyak di daerah Tambaksari sejumlah 4440 orang, dengan rincian sejumlah 1153 di Kelurahan Rangkah, sejumlah 1227 di Kelurahan Pacar Keling, dan sejumlah 2060 di Kelurahan Gading (Dinas Kesehatan Kota Surabaya, 2016).

\section{METODE PENELITIAN}

Penelitian ini merupakan penelitian cross sectional yang dilakukan pada 100 subjek penelitian yang terdiri dari wanita yang sedang ataupun pernah menggunakan alat kontrasepsi pil KB. Penentuan subjek penelitian menggunakan teknik sampling non probability sampel dengan metode accidental sampling. Hal ini berdasarkan keterbatasan waktu dan biaya dari peneliti, sehingga tidak bisa didapatkan data pasti terkait wanita yang menggunakan alat kontrasepsi pil KB.

Subjek dipilih sesuai data inklusi dengan cara peneliti mendatangi rumah-rumah penduduk Kecamatan Tambaksari, Kota Surabaya, dan meminta data diri subjek yang sedang atau pernah menggunakan alat kontrasepsi Pil KB. Kemudian subjek diberikan informasi penelitian dan lembar informed consent sebagai bukti kesediaan responden menjadi subjek penelitian. Selanjutnya peneliti mempersilahkan subjek untuk mengisi kuesioner.

Kriteria inklusi yang memenuhi dalam penelitian ini yaitu:

1. Wanita yang sedang atau pernah menggunakan kontrasepsi pil KB minimal 5 tahun yang lalu, di Kecamatan Tambaksari, Kota Surabaya.

2. Wanita yang sedang atau pernah menggunakan pil $\mathrm{KB}$ minimal 5 tahun yang lalu dengan tujuan mencegah kehamilan.
3. Bersedia mengisi lembar persetujuan penelitian dan mengisi lembar kuesioner dengan lengkap.

Kriteria eksklusi yang tidak dapat memenuhi penelitian ini yaitu:

1. Tidak bisa berkomunikasi Bahasa Indonesia dengan baik.

2. Tidak mengingat pengalaman menggunakan kontrasepsi pil KB.

Persiapan penelitian dimulai dengan membuat surat izin penelitian yang ditujukan kepada puskesmas setempat. Terdapat tiga puskesmas di masing-masing kelurahan, Kecamatan Tambaksari, yaitu Puskesmas Pacarkeling, Puskesmas Gading, dan Puskesma Rangkah. Setelah pihak puskesmas memberikan izin, kemudian kami mempersiapkan kuesioner dan souvenir yang akan diberikan di akhir wawancara kepada subjek penelitian.

Kuesioner yang digunakan untuk pengambilan data penelitian menggunakan kuesioner yang telah divalidasi dalam penelitian Vivian (2018) yang dilakukan di Kalimantan Barat.

Uji validitas menggunakan program "IBM SPSS Statistics 22 Lisensi UGM No.24/UGM/KU/CEBU.4/PELTH/2018" diperoleh hasil uji validitas yaitu $100 \%$ valid dan hasil uji reliabilitas dengan data nilai alpha sebesar 0,743 (syarat alfa >0,6) sehingga kuesioner yang akan digunakan dalam penelitian sudah reliabel. Uji reliabilitas ini dilakukan pada 30 orang responden. Kuesioner terdiri dari pernyataan yang terbagi menjadi tiga dimensi dengan rincian pada Tabel 1 . Pernyataan dapat berupa salah dan benar.

Tabel 1. Rincian dimensi dalam kuesioner

\begin{tabular}{lll}
\hline \hline Dimensi & Benar & Salah \\
\hline KB & $1,3,5$ & $2,4,6$ \\
\hline Kontrasepsi & $7,9,11,13,15$, & $8,10,12,14$, \\
& 17 & 16,18 \\
\hline Regimen Dosis & $19,21,23$ & $20,22,24$ \\
\hline \hline
\end{tabular}

(Sumber: Vivian, 2018)

Penilaian kategori tingkat pengetahuan menggunakan pengelompokkan berdasarkan penelitian oleh Vivian (2018) pada Tabel 2.

Tabel 2. Penilaian Kategori Tingkat

\begin{tabular}{ll}
\hline \hline Kategori Tingkat Pengetahuan & Nilai \\
\hline Kurang Baik & $\leq 8$ \\
\hline Baik & $9-16$ \\
\hline Sangat Baik & $17-24$ \\
\hline \hline
\end{tabular}

(Sumber: Vivian, 2018)

Data yang telah didapatkan diolah dengan uji statistika. Uji normalitas menggunakan metode Kolmogorov-Smirnov. Selanjutnya pengujian nonparametrik dua sampel yang tidak saling 
berhubungan menggunakan Uji Mann-Whitney yang bertujuan untuk membantu peneliti dalam membedakan hasil dua kelompok dengan dua kriteria yang berbeda dalam hal ini yaitu tingkat pengetahuan dan keberhasilan penggunaan pil KB (Sujarweni, 2015). Derajat kepercayaan yang digunakan dalam penelitian ini sebesar $95 \%(\alpha=$ 0,05 ) sehingga jika nilai signifikansi $<0,05$ (sig. $<0,05$ ) maka ada hubungan antara tingkat pengetahuan masyarakat dengan keberhasilan penggunaan alat kontrasepsi pil KB.

\section{HASIL DAN PEMBAHASAN}

Dari hasil survei didapatkan 100 sampel ibu yang sedang ataupun pernah menggunakan pil KB untuk kontrasepsi di Kecamatan Tambaksari, Surabaya. Berdasarkan Tabel 3, dapat diketahui bahwa usia ibu yang paling banyak menggunakan pil KB adalah pada usia 30-39 tahun. Pada usia tersebut pasangan suami istri merencanakan program menghentikan keinginan untuk menambah anak. Hal ini dapat dipahami karena wanita berusia 35 tahun ke atas memiliki risiko kematian lebih besar akibat hamil dan melahirkan (Sibuea et al., 2013).

Berdasarkan Tabel 3, rata-rata responden yang menggunakan pil KB adalah lulusan SMA, yaitu sebanyak 47 responden. Namun, tingginya pendidikan ibu tidak berkorelasi dengan tingkat pengetahuan mengenai penggunaan pil KB (Infodatin, 2014). Berdasarkan data, sebanyak 76 responden merupakan ibu rumah tangga dan sisanya bekerja sebagai karyawan swasta, wiraswasta, dll.

Tabel 3. Demografi responden dari hasil penelitian, $n=100$

\begin{tabular}{lc}
\hline $\begin{array}{c}\text { Data Demografi dalam } \\
\text { Kuesioner }\end{array}$ & n (\%) \\
\hline Usia & $1(1)$ \\
\hline$<20$ & $18(18)$ \\
\hline $20-29$ & $43(43)$ \\
\hline $30-39$ & $28(28)$ \\
\hline $40-49$ & $9(9)$ \\
\hline $50-59$ & $1(1)$ \\
\hline$>59$ & $2(2)$ \\
\hline Pendidikan & $21(21)$ \\
\hline Tidak Tamat SD & $24(24)$ \\
\hline SD & $47(47)$ \\
\hline SMP & $6(6)$ \\
\hline SMA & $76(76)$ \\
\hline Perguruan Tinggi & $8(8)$ \\
\hline Pekerjaan & $10(10)$ \\
\hline Karyaman Rangga & $6(6)$ \\
\hline Wiraswasta & \\
\hline Lain-Lain & \\
\hline \hline
\end{tabular}

Berdasarkan Tabel 4, jenis Pil KB yang banyak digunakan oleh responden adalah Pil KB Andalan dan Microgynon karena biaya dan keterjangkauan untuk mendapatkan pil jenis tersebut dianggap mudah oleh masyarakat setempat. Responden paling banyak mendapatkan info mengenai cara penggunaan pil KB melalui bidan. Kemudian sebanyak $96 \%$ responden mengaku mendapatkan pil KB dengan cara membeli sendiri di apotek.

Berdasarkan Tabel 4, dari 100 responden 63 diantaranya menyatakan bahwa mereka tidak mengalami efek samping apapun dari penggunaan pil KB. Sedangkan dari data tersebut juga diperoleh informasi bahwa dari 100 responden, 37 di antaranya menyatakan mengalami efek samping dari penggunaan pil KB. Efek samping yang paling banyak dialami oleh responden adalah berat badan naik dan kepala pusing. Berdasarkan teori, insiden efek samping kontrasepsi pil KB yang sering ditemukan adalah efek samping ringan dan umumnya bersifat sementara. Efek samping yang timbul pada pasien berbeda-beda seperti mual, mastalgia, break trough bleeding, sakit kepala, muncul jerawat, dan bertambahnya berat badan (Staf Pengajar Departemen Farmakologi Fakultas Kedokteran Universitas Sriwijaya, 2008). Sehingga efek samping yang dirasakan masyarakat merupakan efek samping yang umum terjadi.

Berdasarkan Tabel 4, didapatkan informasi bahwa obat lain yang paling banyak digunakan bersamaan dengan pil KB adalah obat antihipertensi. Obat yang digunakan oleh pasien tidak berinteraksi dengan pil KB (Sweetman, 2009). Masyarakat Desa Tambaksari rata-rata menggunakan pil KB selama satu hingga empat tahun. Berdasarkan informasi dari desa setempat program KB baru saja digalakkan dengan adanya penyuluhan-penyuluhan rutin sejak tahun 2017 sehingga diharapkan pemahaman masyarakat akan pentingnya penggunaan KB untuk memberi jarak kelahiran anak juga mulai meningkat.

Dari Tabel 4, diketahui bahwa selama penggunaan pil KB, 78 responden menyatakan tidak pernah mengalami kehamilan yang tidak diinginkan dan 22 responden mengalami kehamilan yang tidak diinginkan. Tingginya kegagalan kontrasepsi pil KB bisa disebabkan karena tingkat pengetahuan yang masih rendah ataupun tingkat kepatuhan penggunaan pil $\mathrm{KB}$ sebagai alat kontrasepsi. Pemahaman terhadap instruksi penggunaan jenis pil $\mathrm{KB}$, merupakan faktor penting dalam keberhasilan penggunaan pil KB (Niven, 2002).

Berdasarkan hasil penelitian dari 100 responden, data hasil survei yang diperoleh diuji normalitasnya dengan metode KolmogorovSmirnov dan menunjukan hasil bahwa persebaran data tidak normal, sehingga digunakan uji Mann- 
Whitney untuk menjelaskan hubungan antara tingkat pengetahuan dengan keberhasilan pil KB.

Tabel 4. Data perilaku responden terhadap penggunaan pil $\mathrm{KB}, \mathrm{n}=100$

\begin{tabular}{|c|c|}
\hline $\begin{array}{c}\text { Data Perilaku dalam } \\
\text { Kuesioner }\end{array}$ & n $(\%)$ \\
\hline \multicolumn{2}{|l|}{ Jenis Pil } \\
\hline Andalan & $45(45)$ \\
\hline Diane-35 & $2(2)$ \\
\hline Trinordiol-28 & $3(3)$ \\
\hline Microgynon & $28(28)$ \\
\hline Kombinasi & $3(3)$ \\
\hline Lain-Lain & $19(19)$ \\
\hline \multicolumn{2}{|l|}{ Sumber Informasi } \\
\hline Dokter & $16(16)$ \\
\hline Bidan & $57(57)$ \\
\hline Apoteker & $5(5)$ \\
\hline Keluarga & $4(4)$ \\
\hline Lain-lain & $18(18)$ \\
\hline \multicolumn{2}{|l|}{ Cara Memperoleh Pil KB } \\
\hline Membeli Sendiri & $96(96)$ \\
\hline BPJS & $4(4)$ \\
\hline \multicolumn{2}{|l|}{ Efek Samping Pil KB } \\
\hline $\mathrm{Ya}$ & $37(37)$ \\
\hline Tidak & $63(63)$ \\
\hline \multicolumn{2}{|l|}{ Macam Efek Samping } \\
\hline Capek & $63(63)$ \\
\hline Gemuk & $1(1)$ \\
\hline Gemuk dan Kulit & $10(10)$ \\
\hline Gelap & $1(1)$ \\
\hline Gemuk, Mual, dan Pusing & $1(1)$ \\
\hline Haid Kurang Lancar & $3(3)$ \\
\hline Mual & $7(7)$ \\
\hline Mual dan Flek Hitam & $1(1)$ \\
\hline Mual dan Pusing & $5(5)$ \\
\hline $\begin{array}{l}\text { Pernah Menstruasi } 2 \text { kali } \\
\text { dalam Sebulan }\end{array}$ & $1(1)$ \\
\hline Pusing & $7(7)$ \\
\hline \multicolumn{2}{|l|}{ Obat Lain yang Digunakan } \\
\hline Tidak ada & $93(93)$ \\
\hline Antihipertensi & $2(2)$ \\
\hline Flu (Flucadex) & $1(1)$ \\
\hline Insa & $1(1)$ \\
\hline Mexon (obat alergi) & $1(1)$ \\
\hline Neuralgin & $1(1)$ \\
\hline Vitamin C & $1(1)$ \\
\hline \multicolumn{2}{|l|}{ Lama Penggunaan } \\
\hline $0-1$ tahun & $28(45)$ \\
\hline $1,1-2$ tahun & $13(2)$ \\
\hline $2,1-3$ tahun & $11(3)$ \\
\hline $3,1-4$ tahun & $10(28)$ \\
\hline $4,1-5$ tahun & $5(3)$ \\
\hline $5,1-6$ tahun & $2(2)$ \\
\hline $6,1-7$ tahun & $4(4)$ \\
\hline $7,1-8$ tahun & $5(5)$ \\
\hline $8,1-9$ tahun & $2(2)$ \\
\hline $9,1-10$ tahun & $5(5)$ \\
\hline$>10$ tahun & $15(15)$ \\
\hline \multicolumn{2}{|l|}{ Kehamilan } \\
\hline Pernah & $22(22)$ \\
\hline TIdak Pernah & $78(78)$ \\
\hline
\end{tabular}

Tabel 5. Analisis Hubungan Tingkat Pengetahuan dengan Keberhasilan Pil KB Uji Mann Whitney, $\mathbf{n = 1 0 0}$

\begin{tabular}{llc}
\hline \hline & Kehamilan & n (\%) \\
\hline Tingkat & Pernah & $22(22)$ \\
\cline { 2 - 3 } Pengetahuan & Tidak Pernah & $78(78)$ \\
\hline Asymp. Sig. & & 0,669 \\
\hline \hline
\end{tabular}

Dari hasil uji statistik dengan menggunakan uji Mann-Whitney diperoleh nilai Asymp. Sig. atau $\mathrm{P}$ Value $=0,669$. Berdasarkan data tersebut didapat bahwa nilai Asymp. Sig. atau P Value lebih besar dari 0,05 sehingga Ho diterima (Tabel 5).

Hasil analisis data menunjukan tidak terdapat perbedaan tingkat pengetahuan antara masyarakat yang berhasil maupun tidak dalam penggunaan pil KB. Hal ini menunjukkan bahwa keberhasilan pil $\mathrm{KB}$ tidak selalu dipengaruhi oleh tinggi rendahnya pengetahuan akseptor KB.

Faktor lain yang dapat mempengaruhi keberhasilan pil $\mathrm{KB}$ adalah tingkat kepatuhan penggunaan, salah satunya merupakan pemahaman tentang instruksi. Tidak seorang pun bisa mematuhi instruksi apabila salah paham dengan instruksi yang diberikan, sehingga pemahaman akan mempengaruhi kepatuhan akseptor $\mathrm{KB}$ dalam mengkonsumsi pil KB (Niven, 2002). Jadi yang perlu dilakukan untuk menghindari kegagalan pada pengguna pil $\mathrm{KB}$ adalah dengan melakukan konsultasi rutin serta memberikan informasi secara tepat mengenai tata cara penggunaan dan efek samping yang mungkin terjadi. Selain itu juga bisa dilakukan penyuluhan pada akseptor pil KB mengenai pentingnya mengkonsumsi pil KB secara teratur (Yenie, 2016).

Walaupun tidak terdapat perbedaan tingkat pengetahuan antara masyarakat yang berhasil maupun tidak dalam penggunaan pil KB, namun jawaban setiap pertanyaan dalam kuesioner dapat dipertimbangkan dalam analisis. Dalam hal ini, pertimbangan analisis dilakukan berdasarkan frekuensi nilai setiap dimensi dalam kuesioner yang dapat menunjukkan jumlah responden dalam tingkat pengetahuan yang berbeda. Data kuesioner menunjukkan bahwa rata-rata nilai kuesioner untuk dimensi $\mathrm{KB}$ adalah 4,22 dengan nilai minimum 2 dan maksimum 6. Sedangkan dimensi kontrasepsi memiliki nilai rata-rata 8,40 dengan nilai minimum 5 dan nilai maksimum 12. Dan untuk dimensi regimen dosis memiliki rata-rata 4,41 dengan nilai minimum 2 dan nilai maksimum 6.

Pada tingkat pengetahuan dalam dimensi KB, nilai di atas rata-rata adalah 5 dan 6 , yang masingmasing memiliki frekuensi 29 dan 4. Artinya hanya terdapat 33 responden yang memiliki nilai di atas rata-rata sementara 67 lainnya memiliki nilai di bawah rata-rata. Jumlah ketidakberhasilan Pil KB sebagai kontrasepsi yang terjadi adalah $22 \%$. 
Berdasarkan Tabel 6, keberhasilan KB sejumlah $78 \%$, hanya terdapat 33 responden diantaranya yang memiliki nilai dimensi $\mathrm{KB}$ di atas rata-rata.

Tabel 6. Sebaran nilai kuesioner

\begin{tabular}{ll}
\hline \hline Dimensi KB & \\
\hline Nilai & Jumlah $(\%)$ \\
\hline $0-2$ & $2(2)$ \\
\hline $3-4$ & $65(65)$ \\
\hline $5-6$ & $33(33)$ \\
\hline Dimensi Kontrasepsi & \\
\hline Nilai & Jumlah (\%) \\
\hline $0-4$ & $0(0)$ \\
\hline $5-8$ & $53(53)$ \\
\hline $9-12$ & $47(47)$ \\
\hline Dimensi Regimen Dosis & \\
\hline Nilai & Jumlah $(\%)$ \\
\hline $0-2$ & $4(4)$ \\
\hline $3-4$ & $42(42)$ \\
\hline $5-6$ & $54(54)$ \\
\hline
\end{tabular}

Pada dimensi kontrasepsi, nilai kuesioner cukup bervariasi. Nilai di atas rata-rata yaitu 9, 10, 11, dan 12 dengan frekuensi masing-masing adalah $29,10,5$ dan 3 . Hanya terdapat 3 responden yang menjawab seluruh pertanyaan dengan benar dan 2 responden hanya menjawab 5 jawaban benar dari 12 pertanyaan. Sejumlah 47 responden mendapat nilai di atas rata-rata dan 53 lainnya di bawah ratarata.

Pada tingkat pengetahuan dalam dimensi regimen dosis, frekuensi nilai di atas rata-rata diperoleh oleh nilai kuesioner 5 dan 6 . Berdasarkan Tabel 6, 54 responden yang memiliki nilai di atas rata-rata, dan 46 responden lainnya memiliki nilai di bawah rata-rata. Dalam hal ini, 54 responden tersebut dapat berperan dalam keberhasilan Pil KB yang memiliki frekuensi 78 .

Persebaran nilai kuesioner dengan nilai dibawah rata-rata yang lebih tinggi dibanding diatas rata-rata terdapat pada dimensi KB dan Kontrasepsi. Pada dimensi tersebut menanyakan terkait hal umum mengenai tujuan, sasaran program $\mathrm{KB}$, dan macam-macam metode kontrasepsi. Oleh karena itu perlu ditingkatkan pengetahuan masyarakat mengenai hal tersebut sebagai upaya meningkatkan keberhasilan program KB.

\section{KESIMPULAN}

Tidak ada perbedaan signifikan tingkat pengetahuan masyarakat yang berhasil dalam penggunaan alat kontrasepsi pil KB maupun yang tidak berhasil. Akan tetapi, perlu dilakukan promosi kesehatan mengenai macam-macam metode kontrasepsi terutama metode kontrasepsi jangka panjang yang memiliki angka keberhasilan lebih tinggi dibandingkan dengan metode pil KB. Pengetahuan mengenai tingkat keberhasilan, keuntungan dan kerugian, serta cara penggunaan untuk masing-masing metode kontrasepsi perlu diperkenalkan kepada masyarakat agar masyarakat mampu mempertimbangkan pilihannya dalam program keluarga berencana.

\section{UCAPAN TERIMA KASIH}

Penulis menyadari bahwa dalam penulisan makalah ini tidak lepas dari bantuan dan dukungan berbagai pihak baik secara langsung maupun tidak langsung. Oleh karena itu, penulis ingin mengucapkan terima kasih kepada:

1. Ibu Gusti Noorizka Veronika Achmad, S.Si., Apt., M.Sc. sebagai dosen pembimbing yang telah memberikan kritik dan saran pada penelitian ini.

2. Semua anggota Perangkat Desa di daerah Tambak Sari yang telah membantu mempermudah dalam melakukan survey.

3. Ibu-ibu di daerah Tambak Sari yang sudah bersedia menjadi target responden peneliti dalam menyelesaikan makalah ini.

\section{PUSTAKA}

Badan Pusat Statistik, 2013. Proyeksi Penduduk Indonesia 2010-2035. Jakarta: Badan Pusat Statistik. pp. 23-25.

Dinas Kesehatan Kota Surabaya, 2016. Profil Kesehatan Provinsi Jawa Timur Tahun 2016. Surabaya: Dinas Kesehatan Kota Surabaya, pp. 10-12.

Ermawati, I, 2013. Hubungan Antara Tingkat Kepatuhan dengan Keberhasilan Akseptor Pil KB. Jurnal Sain Med : 5 (2), pp 47-51.

Fajrin, F.I., \& Oktaviani, L., 2011. Hubungan Disiplin Waktu dalam Pemakaian Pil KB Kombinasi dengan Kegagalan Akseptor. Jurnal Midpro, edisi 2, pp. 1.

Handayani, S, 2010. Buku Ajar Pelayanan Keluarga Berencana.Yogyakarta: Pustaka Rihama.

Hartanto, H, 2010. Keluarga Berencana dan Kontrasepsi. Jakarta: Pustaka Sinar Harapan, pp. 22-27.

Infodatin, 2014. Situasi dan Analisis Keluarga Berencana. Jakarta Selatan: Kementerian Kesehatan RI.

Niven, N, 2002. Psikologi Kesehatan. Jakarta: Kedokteran EGC, pp. 192-196.

Perwiraningtyas, P., \& Prasetyo, N.A., 2016. Hubungan Jenis Metode Kontrasepsi dengan Kehamilan Tidak Diinginkan (KTD) Pada Pasangan Usia Subur (PUS). Jurnal Ners LENTERA : 4 (1).

Primadi, O, 2013. Situasi Keluarga Berencana di Indonesia. Jakarta: Buletin Jendela Data dan Informasi Kesehatan.

Rahardjo, R, 2008. Kumpulan Kuliah Farmakologi Edisi 2. Jakarta: EGC, pp. 254-256. 
Sibuea, M. D., Tendean H. M. M., dan Wagey, F.W., 2013. Persalinan Pada Usia $\geq 35$ Tahun di RSU Prof. Dr. R. D. Kandou Manado. Jurnal e-Biomedik (eBM) : 1 (1), pp. 484-489.

Sujarweni, V. W., 2015. SPSS untuk Penelitian, Yogyakarta: Pustaka Baru Press, pp. 52-85.

Sweetman, S., 2009. Martindale $36^{\text {th }}$ edition. London: The Pharmaceutical Press, pp. 2058-2071.

Vivian, 2018. Pengaruh Penyuluhan terhadap Tingkat Pengetahuan Ibu dalam Penggunaan Pil KB di Puskesmas Sungai Durian Sintang Kalimantan Barat.
SKRIPSI. Fakultas Farmasi Universitas Sanata Dharma Yogyakarta.

Winner, B., Peipert, J. F., Zhao, Q., Buckel, C. Madden, T., Allsworth, J. E., 2012. Effectiveness of LongActing Reversible Contraception. The new england journal of medicine, pp. 1998-2007.

Yenie, H, 2016. Hubungan Kepatuhan Akseptor Pil KB Dengan Kegagalan Kontrasepsi Pil di Kabupaten Lampung Selatan. Jurnal Keperawatan: XII (2).

WHO, 2015. World Health Statistics 2015. World Health Organization. 